\title{
Analisis Keterampilan Metakognitif IPA Siswa Kelas VIII di SMP Katolik Barto Mangaran
}

\author{
Aprilyanto Totopandey ${ }^{1^{*}}, \mathrm{Ni}$ Wayan Suriani ${ }^{2}$ \\ 1,2Jurusan Pendidikan IPA, FMIPA, Universitas Negeri Manado \\ *e-mail: aprilyanto.totopandey94@gmail.com
}

\begin{abstract}
Abstrak. Penelitian ini bertujuan untuk menganalisis keterampilan metakognitif IPA siswa kelas VIII di SMP Katolik Barto Mangaran yang berlokasi di Kepulauan Kabaruan, Kabupaten Kepulauan Talaud. Jenis penelitian kualitatif ini menggunakan metode deskriptif eksploratif. Populasinya adalah seluruh siswa SMP Katolik Barto Mangaran tahun ajaran 2020/2021, sedangkan sampel penelitian adalah 17 siswa kelas VIII. Sampel diperoleh menggunakan teknik purposive sampling. Instrumen penelitian yang digunakan berupa angket keterampilan metakognitif yang diadaptasi dari Schraw \& Dennison. Teknik analisis deskriptif digunakan untuk menganalisis data dalam penelitian ini. Hasil penelitian menunjukkan skor rata-rata keterampilan metakognitif siswa sebesar 30,76 dengan persentase 48,07\%. Dengan demikian, dapat disimpulkan bahwa keterampilan metakognitif siswa kelas VIII di SMP Katolik Barto Mangaran berada pada kategori sedang.
\end{abstract}

Kata kunci: keterampilan metakognitif siswa

\begin{abstract}
This study aims to analyze the science metacognitive skills of eighth graders at SMP Katolik Barto Mangaran located in the Kabaruan Islands, Talaud Islands Regency. This type of qualitative research uses an exploratory descriptive method. The population is all SMP Katolik Barto Mangaran students for the 2020/2021 academic year, while the research sample is 17 students of class VIII. Samples were obtained using purposive sampling technique. The research instrument used was a metacognitive skill questionnaire adapted from Schraw \& Dennison. The descriptive analysis technique was used to analyze the data in this study. The results showed that average score of students' metacognitive skills was 30.76 with a percentage of $48.07 \%$. Thus, it can be concluded that the metacognitive skills of eighth graders at SMP Katolik Barto Mangaran are in the medium category.

Keywords: students' metacognitive skills

Diterima 15 November 2021 | Disetujui 02 Desember 2021 | Diterbitkan 31 Desember 2021
\end{abstract}

\section{PENDAHULUAN}

Keterampilan metakognitif adalah kemampuan siswa untuk mengontrol proses belajarnya, mulai dari tahap perencanaan, memilih strategi yang tepat sesuai masalah yang dihadapi, kemudian memonitor kemajuan dalam belajar dan secara bersamaan mengoreksi jika ada kesalahan yang terjadi selama memahami konsep, menganalisis keefektifan dari strategi yang dipilih (Risnanosanti, 2008). Pengetahuan metakognisi merujuk pada pengetahuan umum tentang bagaimana seseorang belajar dan memproses informasi, seperti pengetahuan seseorang tentang proses belajarnya sendiri (Sudjana \& Wijayanti, 2018).

Eriawati \& Khairil (2013) menyatakan bahwa keterampilan metakognitif diperlukan untuk kesuksesan belajar karena keterampilan metakognitif dapat memungkinkan siswa mampu mengelola kecakapan kognitif atau pengetahuannya dan mampu melihat kelemahannya sehingga dapat dilakukan perbaikan pada tindakan- 
tindakan berikutnya. Lebih lanjut, dinyatakan bahwa siswa yang mampu menggunakan keterampilan metakognitifnya akan memiliki prestasi yang lebih baik dibandingkan dengan siswa yang tidak menggunakan keterampilan metakognitifnya. Hal ini disebabkan karena keterampilan metakognitif dapat memungkinkan siswa melakukan perencanaan, mengikuti perkembangan, dan memantau proses belajarnya.

Hasil wawancara yang peneliti lakukan dengan guru mata pelajaran IPA di SMP Katolik Barto Mangaran mengungkapkan bahwa hasil belajar kognitif siswa rendah, guru belum menuntun siswa untuk mampu belajar mandiri, dan guru belum pernah melatih dan mengukur keterampilan metakognitif siswa. Disisi lain, apabila kita melihat rumusan dimensi pengetahuan lulusan SMP dalam Standar Kompetensi Lulusan (SKL) disana dituliskan "memiliki pengetahuan faktual, konseptual, prosedural, dan metakognitif pada tingkat teknis dan spesifik sederhana berkenaan dengan ilmu pengetahuan, teknologi, seni, dan budaya" (Kemendikbud, 2016). Hal ini menunjukkan bahwa kemampuan metakognitif menjadi salah satu hal penting yang harus dicapai siswa pada jenjang SMP. Oleh sebab itu, peneliti bermaksud melakukan penelitian terkait analisis keterampilan metakognitif IPA siswa di SMP Katolik Barto Mangaran.

\section{METODE PENELITIAN}

Penelitian ini dilaksanakan di SMP Katolik Barto Mangaran pada bulan Januari 2021. Populasi dalam penelitian ini adalah seluruh siswa SMP Katolik Barto Mangaran, sedangkan sampel penelitian yang kemudian disebut responden adalah 17 siswa kelas VIII pada tahun ajaran 2020/2021. Sampel yang digunakan diperoleh dengan menggunakan teknik purposive sampling.

Penelitian ini merupakan jenis penelitian kualitatif dengan metode penelitian deskriptif eksploratif. Penelitian deskriptif eksploratif bertujuan untuk menggambarkan suatu fenomena, dalam penelitian ini tidak dimaksud untuk menguji hipotesis tertentu tetapi hanya menggambarkan apa adanya suatu variabel, gejala atau keadaan (Arikunto, 2013).

Instrumen penelitian yang digunakan dalam penelitian ini berupa angket keterampilan metakognitif yang diadaptasi dari Schraw \& Dennison (dalam Sumampouw, 2011) yang dapat dilihat pada Tabel 1.

Tabel 1. Rubrik keterampilan metakognitif Schraw \& Dennison

\begin{tabular}{ll}
\hline No & \multicolumn{1}{c}{ Indikator } \\
\hline 1 & $\begin{array}{l}\text { Perencanaan } \\
\text { Perencanaan, penentuan tujuan, dan } \\
\text { pengalokasian sumber bahan terutama } \\
\text { untuk belajar. }\end{array}$ \\
\hline 2 & $\begin{array}{l}\text { Strategi mengelola informasi } \\
\text { Urutan keterampilan atau strategi yang } \\
\text { digunakan untuk memperoleh informasi } \\
\text { secara lebih efisien. }\end{array}$ \\
\hline 3 & $\begin{array}{l}\text { Monitoring } \\
\text { Penilaian strategi belajar seseorang yang } \\
\text { sedang ia gunakan. }\end{array}$ \\
\hline 4 & $\begin{array}{l}\text { Strategi perbaikan atau langkah yang } \\
\text { dilakukan untuk mengkoordinasikan } \\
\text { kesalahan pemahaman atau perolehan. }\end{array}$ \\
\hline 5 & $\begin{array}{l}\text { Evaluasi } \\
\text { Analisis perolehan dan efektivitas } \\
\text { strategi pada akhir kegiatan belajar. }\end{array}$ \\
\hline
\end{tabular}

(Sumampouw, 2011)

Berdasarkan Tabel 1, dapat dilihat bahwa indikator keterampilan metakognitif yang diadaptasi dari Schraw \& Dennison (dalam Sumampouw, 2011), terdiri dari lima indikator yakni perencanaan, strategi mengelola informasi, monitoring, strategi perbaikan dan evaluasi.

Data dalam penelitian ini diperoleh dengan menggunakan teknik angket. Teknik angket digunakan untuk mengetahui kategori keterampilan metakognitif siswa. Teknik angket dilakukan dengan menyebarkan angket keterampilan metakognitif kepada siswa.

Data dalam penelitian ini dianalisis menggunakan teknik analisis deskriptif. Teknik analisis deskriptif digunakan untuk mengolah data yang terkumpul dari angket keterampilan metakognitif dalam bentuk deskriptif persentase. Data pada angket keterampilan metakognitif 
dinilai dengan skor 1 sampai 4 untuk setiap kriteria alternatif jawaban, yaitu skor 4 untuk pilihan selalu (S), skor 3 untuk pilihan sering (SR), skor 2 untuk pilihan kadang-kadang (KK), dan skor 1 untuk pilihan tidak sama sekali (TSS).

Skor yang diperoleh kemudian dikonversi dalam bentuk persentase dengan perhitungan menggunakan rumus $P=\frac{\Sigma F}{\Sigma N} \times 100 \%$, dimana $\mathrm{P}$ menunjukkan persentase, $\mathrm{F}$ menunjukkan skor jawaban responden dan $\mathrm{N}$ menunjukkan skor maksimal (Riduwan \& Kuncoro, 2017).

Hasil persentase kemudian ditafsirkan kedalam kriteria penafsiran seperti pada Tabel 2 untuk mendapatkan kategori keterampilan metakognitif setiap siswa dan keterampilan metakognitif sampel secara keseluruhan.

Tabel 2. Kriteria penafsiran kategori keterampilan metakognitif

\begin{tabular}{ll}
\hline Persentase (\%) & Kategori \\
\hline $81-100$ & Sangat Tinggi \\
$61-80$ & Tinggi \\
$41-60$ & Sedang \\
$21-40$ & Rendah \\
$<21$ & Sangat Rendah \\
\hline
\end{tabular}

(Sumampouw, 2011)

Berdasarkan Tabel 2, dapat dilihat bahwa penafsiran kategori keterampilan metakognitif dibagi menjadi lima kategori sesuai dengan masing-masing rentang persentase yang diperoleh.

\section{HASIL DAN PEMBAHASAN}

Penelitian ini melaporkan tentang analisis keterampilan metakognitif siswa kelas VIII di SMP Katolik Barto Mangaran yang dilakukan pada bulan Januari 2021. Keterampilan metakognitif siswa diukur melalui angket keterampilan metakognitif oleh Schraw \& Dennison (1994) yang diadaptasi oleh peneliti. Hasil angket keterampilan metakognitif siswa disajikan pada Tabel 3.
Tabel 3. Hasil skor keterampilan metakognitif siswa

\begin{tabular}{llll}
\multicolumn{4}{c}{ metakognitif siswa } \\
\hline Siswa & Skor K.M & Persentase (\%) & Kategori \\
\hline 1 & 24 & 37,50 & Rendah \\
2 & 28 & 43,75 & Sedang \\
3 & 20 & 31,25 & Rendah \\
4 & 34 & 53,13 & Sedang \\
5 & 32 & 50,00 & Sedang \\
6 & 46 & 71,88 & Tinggi \\
7 & 24 & 37,50 & Rendah \\
8 & 44 & 68,75 & Tinggi \\
9 & 39 & 60,94 & Sedang \\
10 & 24 & 37,50 & Rendah \\
11 & 25 & 39,06 & Rendah \\
12 & 49 & 76,56 & Tinggi \\
13 & 32 & 50,00 & Sedang \\
14 & 32 & 50,00 & Sedang \\
15 & 25 & 39,06 & Rendah \\
16 & 25 & 39,06 & Rendah \\
17 & 20 & 31,25 & Rendah \\
\hline Rerata & 30,76 & 48,07 & Sedang \\
\hline
\end{tabular}

Berdasarkan Tabel 3 diketahui nilai rata-rata persentase keterampilan metakongnitif siswa keseluruhan adalah $48,07 \%$ dengan kategori sedang. Keterampilan metakongnitif paling rendah diperoleh siswa 3 dan siswa 17 dengan skor 20 (31,25\%), sedangkan keterampilan metakongnitif paling tinggi diperoleh siswa 12 dengan skor 49 $(76,56 \%)$.

Kategori

keterampilan metakongnitif tinggi diperoleh tiga siswa dengan rata-rata $72,40 \%$, kategori keterampilan metakongnitif sedang diperoleh enam siswa dengan rata-rata $51,30 \%$, sedangkan kategori keterampilan metakongnitif rendah diperoleh delapan siswa dengan rata-rata $36,52 \%$. Rata-rata setiap kategori keterampilan metakognitif yang diperoleh dapat dilihat secara visual pada Gambar 1.

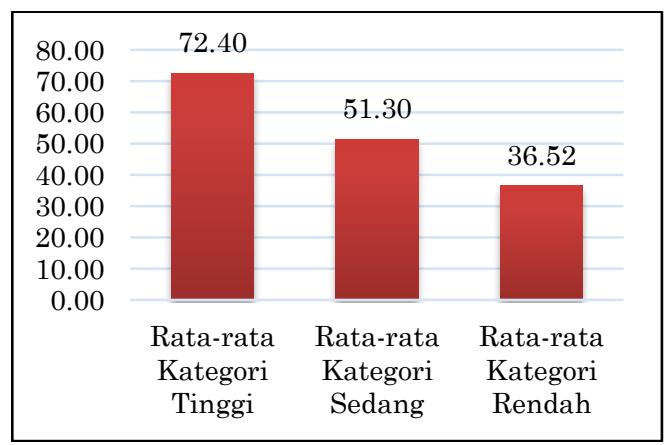

Gambar 1. Grafik setiap kategori keterampilan metakognitif 
Berdasarkan Gambar 1, keterampilan metakognitif yang diperoleh dalam penelitian ini terbagi dalam tiga kategori yaitu tinggi, sedang, dan rendah, sdangkan kategori sangat tinggi dan sangat rendah tidak ada.

Hasil penelitian ini menunjukkan keterampilan metakongnitif seluruh siswa yang dijadikan sampel berada pada kategori sedang karena guru belum pernah melatih dan mengukur keterampilan metakognitif siswa sehingga berdampak pada hasil belajar yang rendah. Hal tersebut senada dengan yang penelitian yang ditemukan Warouw (2016) bahwa rendahnya hasill belajar disebabkan karena belum mengembangkan keterampilan metakognitif. Padahal, Siregar (2019) menyatakan bahwa keberhasilan siswa dalam pembelajaran dipengaruhi oleh kemampuan metakognitif yang dimilikinya.

Kauchak \& Eggen (dalam Warouw, 2016) menjelaskan bahwa keterampilan metakognitif dapat membantu mereka menjadi self-regulated learners yang bertanggungjawab terhadap kemajuan belajarnya sendiri dan mengadaptasi strategi belajarnya mencapai tuntutan tugas. Mengembangkan keterampilan metakognitif pembelajar berarti membangun fondasi untuk belajar secara aktif. Keterampilan metakognitif juga diperlukan untuk kesuksesan belajar, mengingat hal ini memungkinkan pelajar mampu mengelola kecakapan kognitif dan mampu melihat atau menemukan kelemahannya yang nantinya akan diperbaiki dengan kecakapan kognitif berikutnya. Oleh sebab itu, guru sebagai perancang kegiatan belajar dan pembelajaran mempunyai tanggungjawab untuk mengembangkan keterampilan metakognitif siswa.

\section{KESIMPULAN}

Berdasarkan penelitian yang dilakukan, peneliti menyimpulkan bahwa keterampilan metakognitif siswa kelas VIII SMP Katolik Barto Mangaran berada pada kategori sedang dengan persentase $48,07 \%$.

\section{DAFTAR PUSTAKA}

Arikunto, S. (2013). Dasar-dasar evaluasi pendidikan. Jakarta: Bumi Aksara.

Eriawati, E., \& Khairil, K. (2013). Aplikasi metakognitif dalam keterampilan monitoring pada konsep ekosistem. Jurnal EduBio Tropika, 1(1), 51-56.

Kemendikbud. (2016). Permendikbud Nomor 20 Tahun 2016 tentang standar kompetensi lulusan pendidikan dasar dan menengah. Jakarta: Kementerian Pendidikan dan Kebudayaan.

Riduwan \& Kuncoro, E. A. (2017). Cara menggunakan dan memakai path analysis (analisis jalur). Bandung: Alfabeta.

Risnanosanti, R. (2008). Kemampuan metakognitif siswa dalam pembelajaran matematika. Pythagoras: Jurnal Pendidikan Matematika, 4(1), 86-98.

Schraw, G., \& Dennison, R. S. (1994). Assessing metacognitive awareness. Contemporary Educational Psychology, 19(4), 460-475.

Siregar, S. (2019). Analisis keterampilan metakognitif dan sikap ilmiah siswa melalui metode pembelajaran inkuiri. BIOTIK: Jurnal Ilmiah Biologi Teknologi dan Kependidikan, 7(2), 141 145.

Sudjana, D., \& Wijayanti, I. E. (2018). Analisis keterampilan metakognitif pada materi kelarutan dan hasil kali kelarutan melalui model pembelajaran pemecahan masalah. EduChemia: Jurnal Kimia dan Pendidikan, 3(2), 206-221.

Sumampouw, H. M. (2011). Kajian perkuliahan dan asesmen genetika dalam memberdayakan keterampilan metakognitif, berpikir tinggkat tinggi, keterampilan proses sains, dan daya retensi mahasisiwa jurusan biologi $\mathrm{S} 1$ dan S2 Universitas Negeri Malang. Disertasi. Pascasarjana Universitas Negeri Malang.

Warouw, Z. W. M. (2016). Pembelajaran Reciprocal Teaching dan Metakognitif (RTM) yang memberdayakan keterampilan metakognitif dan hasil belajar biologi siswa SMP. Jurnal Ilmu Pendidikan, 17(2): 162-171. 